\title{
Pengembangan Peralatan Simulasi Peralatan Aliran Daya Berbasis Fast Decoupled-Dependent Newton-Raphson dengan Program Interface-Based Delphi
}

\author{
Makmur Saini ${ }^{1, a}$, Remigius Tandioga ${ }^{1}$, Andareas Pangkung ${ }^{1}$ dan A. M. Shiddiq Yunus ${ }^{1}$ \\ ${ }^{1}$ Jurusan Teknik Mesin, Jalan Perintis Kemerdekaan KM. 10, Makassar, 90245, Indonesia \\ a makmur.saini@poliupg.ac.id
}

\begin{abstract}
On one hand, the particular objective of this research is to yield the software program in order to control efficiently the important aspects in electric power systems which can be implemented in industries. In the other hand, the longterm objective is to extend the curriculum, syllabi, laboratory facilities, and to improve the abilities and qualities of graduates continuously either within State Polytechnic of Ujung Pandang or outside. Method used to achieve these objectives is making, design and implementation which will be last for two years. Simulator for generation system in the first stage of the research is balanced six-phase system yielded from the circuit of 3-one phase centre-tap transformers of $220 / 18 \mathrm{~V}, 15 \mathrm{~A}$, as the supply of low-tension 3-phase system, which feeds six one-phase transformer of $18 / 220 \mathrm{~V}, 20 \mathrm{~A}$, whose output as another balanced 3-phase system with $220 \mathrm{~V} /$ phase. From balanced 6-phase system, a balanced 3-phase will simulate generator number 1 and another balanced 3-phase will simulate that of number 2 . Interface which is based on Delphi program is to switch all transmission lines. The result of experiment shows that voltages in the two generator busbars experience the significant drop voltage if they work separately, that are $20.5 \%-36.4 \%$ and $20.5 \%-63.6 \%$ for generator number 1 and number 2 respectively, for one to three load busbars operated sequentially, which also reveals that greatest voltage drop occurs in the generator busbar with most lines supplied. Simulating the two generators working simultaneously, then voltage drops are more significant, that are $65.9 \%-72.7 \%$ and $65.9 \%-79.5 \%$ for generator number 1 and number 2 respectively, for one to three load busbars operated sequentially, which also proves that transformer bank as generator simulator needs to increase its current capacity.
\end{abstract}

Keywords: power flow, simulation equipment, control and computer.

Abstrak-Tujuan dari penelitian ini adalah untuk menghasilkan program software untuk mengatur secara efisien aspek penting dari sistem tenaga listrik yang dpat diimplementasikan ke industri. Di sisi lain, tujuan jangka panjang dari penelitian ini adalah untuk perbaikan kurikulum, silabus fasilitas laboratorium dan untuk meningkatkan kemampuan dan kualitas mahasiswa dilingkup PNUP maupun di luar PNUP. Metode yang digunakan pada penelitian ini adalah rancang bangun dan implementasi yang dilakukan selama dua tahun. Simulator untuk pembangkit tenga listrik pada tahap pertama penelitian ini adalah enam pulsa seimbang yang dihasilkan dari 3 rangkaian satu fasa dengan trafo centre tap
220/18 V, 15 A sebagai suplai sistem 3 fasa untuk enam buah trafo satu-fasa $18 / 220 \mathrm{~V}, 20$ A. untuk sistem 6-fasa seimbang, sebuah sistem 3 fasa seimbang akan mensimulasi generator no. 1 dan sistem 3 fasa seimbang lainnya akan berfungsi untuk mensimulasi generator no. 2. Sistem antar muka berbasis Program Delphi digunakan untuk mensimulasi sistem saluran transmisi. Hasil pengujian menunjukkan bahwa tegangan jatuh pada busbar kedua generator akan sangat signifikan jika kedua generator bekerja secara terpisah yakni antara $20,5 \%-36,4 \%$ dan Untuk satu sampai tiga busbar beban yang beroperasi secara berurutan, juga menunjukkan bahwa jatuh tegangan terbesar terjadi pada busbar yang paling dibebani. Pada simulasi untuk kedua generator bekerja secara simultan, jatuh tegangan semakin besar yakni $65,9 \%$ - 72,7\% dan $65,9 \%$ - 79,5\% untuk masing-masing generator no. 1. dan no. 2 untuk satu sampai tiga busbar beban yang bekerja secara berurutan yang juga menunjukkan perlunya trafo sebagaimana simulator generator perlu ditingkatkan kapasitasnya.

Kata Kunci-Aliran daya, peralatan simulasi, pengaturan dan komputer.

\section{Pendahuluan}

Sistem tenaga listrik merupakan elemen-elemen kunci dalam masyarakat modern, sehingga dapat dikatakan bahwa sumber daya manusia yang mengoperasikan sistem tenaga listrik modern memainkan suatu peranan yang penting dan vital dalam masyarakat [1]. Dasar dari operasi sistem tenaga listrik (yang selanjutnya disingkat dengan "sistem tenaga" saja) adalah bagaimana prinsipprinsip operasi dan prosedurnya.

Menurut Miller dan Malinowski [1], di sisi pembangkit dilakukan pula kerja paralel antar generator/mesin atau sinkronisasi antara pembangkit dengan sistem interkoneksi. Dalam hal ini terdapat syarat-syarat yang harus dipenuhi, yaitu : putaran fasa kedua sistem sama, putaran listrik antara kedua sistem sama, kedua sistem sefasa atau bila tidak maka beda fasanya sangat kecil, dan kedua sistem mempunyai besar (magnitude) tegangan yang sama. Dalam skala yang 
besar, sistem tenaga yang berada dalam perencanaan perlulah disimulasikan [2]. Tujuan simulasi adalah juga untuk mengetahui unjuk kerjanya sebelum ia dirancang untuk pengembangan selanjutnya.

Dalam operasi sistem tenaga listrik pada umumnya dikenal adanya tiga studi atau analisa dalam menjalankan suatu sistem tenaga listrik. Ketiga macam studi tersebut adalah studi aliran daya (power flow studies), studi hubung-singkat atau studi gangguan (short-circuit/fault studies) dan studi kestabilan (stability studies). Masing-masing studi tersebut mempunyai fungsi dan kegunaan sendiri-sendiri.

Ada tiga tipe dari analisa stabilitas yaitu stabilitas keadaan tunak, stabilitas transien dan stabilitas dinamis. Glover dan Sarma [3] mengemukakan bahwa tujuan dari stabilitas keadaan tunak adalah untuk menjamin bahwa sudut fasa pada saluran transmisi tidak terlalu besar, tegangan busbar berada sedekat mungkin ke nilai nominal, serta peralatan seperti generator, saluran transmisi, transformator dan peralatan lainnya tidak terbebani lebih (overloaded).

Analisa aliran daya merupakan studi dasar dalam menganalisa suatu operasi sistem tenaga listrik, baik untuk perencanaan maupun untuk operasinya [4]. Tujuan utama dari analisa aliran adanya adalah suatu hasil yang menampakkan besar tegangan (V) pada berbagai titik dalam sistem khususnya di setiap titik simpul/busbar (node/bus). Dengan diketahuinya V tadi, maka besaran lainnya seperti daya aktif $(\mathrm{P})$ dan daya reaktif $(\mathrm{Q})$ dapat dihitung. Jika $\mathrm{P}$ dan $\mathrm{Q}$ pada dua buah busbar diketahui maka aliran daya dengan jelas dapat diketahui, serta rugi-rugi daya $(\Delta \mathrm{P}$ dan $\Delta \mathrm{Q})$ dalam saluran penghubung antara kedua busbar dapat pula dihitung. Inilah hakekat dinamainya analisa seperti itu sebagai "analisa aliran daya".

Pada sistem tenaga yang terdiri dari banyak busbar dengan sistem interkoneksi maka metode Newton-Raphson kadang-kadang lebih populer untuk dipakai [5]. Seringkali permasalahan yang ditampilkan dalam persamaan (1) didekati melalui metode NewtonRaphson dengan injeksi arus, yaitu suatu metode yang didasarkan pada Hukum I Kirchoff tentang arus di titik simpul. Tentu saja metode Newton-Raphson tidak semata-mata mempunyai keunggulan. Ini menarik perhatian [6] untuk mengadakan penelitian perbandingan antara metode Newton-Raphson dengan metode lain yaitu Gauss-Seidel.

Pada sistem tenaga yang terdiri dari banyak busbar dengan sistem interkoneksi maka metode Newton-Raphson kadang-kadang lebih populer untuk dipakai. Seringkali permasalahan yang ditampilkan dalam persamaan (1) didekati melalui metode NewtonRaphson dengan injeksi arus, yaitu suatu metode yang didasarkan pada Hukum I Kirchoff tentang arus di titik simpul. Tentu saja metode Newton-Raphson tidak semata-mata mempunyai keunggulan. Ini menarik perhatian [6] untuk mengadakan penelitian perbandingan antara metode Newton-Raphson dengan metode lain yaitu Gauss-Seidel.

Akibat-akibat dari perhitungan aliran daya adalah diketahuinya arah dari aliran daya, dan apabila dibutuhkan suatu distribusi daya yang proporsional maka perlulah suatu pengontrol aliran daya. Efek dari penempatan pengontrol ini telah diteliti oleh [7]. Bahkan kegunaan hasil perhitungan aliran daya adalah untuk meregulasi ulang sistem transmisi berdasarkan alokasi rugi-rugi daya dalam sistem.

Kebutuhan simulasi aliran daya tidak akan jauh dari masalah komputerisasi dan instrumentasi. Sehubungan dengan komputer, maka program perangkat lunak yang pertama kali dikembangkan adalah FORTRAN (formula translator). Hingga kini program tersebut masih dipakai di banyak tempat bahkan sebagai bahasa pemrograman standar (acuan) pada institusiinstitusi tertentu. Program bahasa PASCAL kemudian dibuat untuk mengatasi kerumitan dalam FORTRAN. Kini telah dikembangkan suatu bahasa pemrograman dengan tampilan yang visual yang disebut DELPHI yang dirilis pertama kali dalam Februari 1995. DELPHI merupakan bahasa pemrograman tingkat tinggi (high level language) yang mudah dan nyaman untuk dipakai. Bahkan untuk keperluan database, DELPHI dapat pula dipakai.

Dapat dikatakan secara kasar bahwa Delphi adalah "adik" dari Pascal, sehingga macam-macam syntax pada Pascal, juga dapat digunakan dalam Delphi. Dari Delphi, pemakai dapat masuk ke Pascal. Caranya adalah dengan mengubah compiler pada Delphi. Bahasa pemrograman untuk membuat program adalah Borland Delphi Enterprise yang merupakan bahasa program 
Under Windows. Borland Delphi Enterprise merupakan versi yang ditujukan untuk pengembang dengan aplikasi yang berkomunikasi dengan server SQL, bahkan dapat juga untuk komunikasi : komputer - printer - interface. [8].

Khusus mengenai masalah instrumentasi, sebelum suatu besaran listrik ditampilkan pada komputer untuk dibaca atau dilibatkan dalam suatu program perangkat lunak maka terlebih dilakukan antar-muka (interfacing). Dasar dari interfacing adalah analog to digital converter yang disingkat dengan ADC. Piranti ADC adalah piranti pengubah tegangan masukan yang berasal dari rangkaian analog (besaran listrik analog) menjadi data digital [9]. Piranti ADC ini mempunyai kesesuaian dengan jumlah data I/O pada piranti periferal seperti pencetak (printer).

Secara harafiah kata-kata "interfacing" adalah suatu perlakuan atau usaha untuk menghubungkan muka antara dua buah sistem, yang sistem ini dapat berupa sistem integrasi dari sebuah IC peripheral, atau sistem integrasi dari suatu sistem mikroprosesor.

Pengertian interfacing secara lebih umum, biasanya selalu dihubungkan dengan perlakuan "interfacing" antara suatu sistem rangkaian berbasis mikroprosesor dengan suatu sistem rangkaian luar. Rangkaian luar ini dapat berupa rangkaian saklar, rele, lampu, keyboard, printer, dan lain-lain.

\section{Metode Penelitian}

\section{A. Perancangan dan Pembuatan Maket}

Maket adalah miniatur dari suatu benda yang dijadikan obyek atau perbandingan skala dari suatu benda. Maket pada perancangan sistem ini adalah sebagai visualisasi dari sistem aliran daya yang ada pada praktikum distribusi dan transmisi dimana terdapat dua pembangkit dan lima gardu induk. Adapun bahan-bahan yang digunakan pada pembuatan maket ini sebagai visualisasi adalah sebagai berikut:

a. Gardu Induk

Pada perencanaan sistem ini gardu induk yang akan dibuat berjumlah 5 buah dengan 2 gardu induk mempunyai pembangkit sendiri yang sekaligus sebagai penyuplai daya untuk ketiga gardu induk lainnya. Untuk pembangkit itu sendiri dibuat dua yakni PLTA dan PLTU. Dimana bahan yang digunakan pada pembuatan pembangkit ini adalah karton tebal dan kertas kinstrook yang dibuat sedemikian rupa untuk menunjukkan bahwa pada maket tersebut terdapat dua pembangkit. Sedangkan untuk pembuatan transformator dan ruang panel juga dibuat dari karton tebal dan kertas kinstrook yang terdapat pada masing-masing gardu induk.

b. Tiang-Tiang Transmisi

Pada perencanaan sistem ini dibuat tiang transmisi sebanyak 8 tiang. Untuk tiang-tiang transmisi juga digunakan bahan yang sama pada pembuatan gardu induk. Dimana pada tiang-tiang transmisi terdapat isolator yang terbuat dari manik-manik dan sebuah lampu led yang menandakan adanya hubungan dengan panel kontrol. Kabel-kabel penghubung yang digunakan pada tiang transmisi adalah kawat kecil dengan diameter $\pm 0,1 \mathrm{~mm}$ tanpa dialiri arus listrik.

c. Variasi Lainnya

Untuk membuat suasana maket menjadi lebih hidup dibuat beberapa variasi seperti jalan, jembatan, sungai, pohon-pohon, laut, rumput dan sebagainya. Pada maket ini juga terdapat lampu LED (Light Emitting Diode) yang berfungsi sebagai tanda bahwa maket tersebut berhubungan dengan panel kontrol, dimana on ataupun off-nya lampu-lampu tersebut dapat dikontrol pada panel kontrol. Pemasangan lampu LED ini hanya membutuhkan suplay tegangan 12 volt yang berasal dari catu daya (adaptor) yang dibuat.

\section{B. Perancangan dan Pembuatan Panel Kontrol}

Panel kontrol pada perancangan sistem ini berfungsi sebagai tempat pengukuran aliran daya yang terdapat pada masing-masing saluran dan sebagai pengontrol apabila terjadi gangguan ataupun pemutusan pada tiaptiap saluran, serta sebagai tempat menempelnya alat-alat ukur dan kontrol. Dimana panel tersebut terbuat dari plat aluminium dengan ukuran $100 \mathrm{~cm}$ x $50 \mathrm{~cm}$, sedangkan untuk standnya juga terbuat dari bahan aluminium dengan tinggi $85 \mathrm{~cm}$ dan lebar $95 \mathrm{~cm}$. Sketsa rancangan panel kontrol dan standnya dapat dilihat pada lampiran.

a. Alat-Alat Kontrol

Adapun komponen-komponen pengontrol yang digunakan adalah sebagai berikut

b. Mini Circuit Breaker (MCB) 
Dalam perencanaan sistem ini digunakan mini circuit breaker 1 fasa dengan arus pemutusan sebesar 6 ampere. Dimana alat ini berfungsi sebagai perangkat sistem proteksi yang dipakai untuk memutuskan rangkaian yang mengalami gangguan hubung singkat. Mini circuit breaker bekerja secara otomatis jika terjadi gangguan.

c. Kontaktor

Kapasitas arus kontaktor tergantung pada arus nominal sistem yaitu 5 ampere, namun pada perencanaan ini digunakan kontaktor dengan arus nominal 6 ampere sebanyak 3 buah.

\section{d. Saklar Tekan (Push Button)}

Untuk kapasitas arus push button disesuaikan dengan kapasitas arus kontaktor yakni 6 Ampere. Dimana saklar tekan ini berfungsi untuk memutuskan menghubungkan rangkaian listrik secara manual. Saklar ini terdiri dari kontak normal tertutup (NC) dan normal terbuka (NO). Saklar tekan yang digunakan pada sistem ini sebanyak 3 buah.

\section{e. Komputer}

Komputer berfungsi sebagai prosesor yang melakukan komputasi alat kontrol serta membantu sebagian kerja dari input dan output dari alat kontrol. Untuk program pengontrolan digunakan program DELPHI 7 dan menggunakan sistem Interface untuk menghubungkan komputer dengan panel kontrol.

\section{f. Alat-Alat Ukur}

Adapun alat ukur-ukur yang digunakan pada sistem perancangan ini adalah sebagai berikut :

\section{g. Cos-phi Meter}

Pada perancangan sistem ini digunakan cosphi meter 3 fasa yang berfungsi untuk mengukur faktor daya $(\cos \varphi)$ pada setiap jenis beban yakni beban R, L, dan C.

\section{h. Tang Meter}

Tang meter merupakan alat ukur digital yang didalamnya mencakup voltmeter dan amperemeter. Dimana pada perancangan sistem ini digunakan 3 buah tang meter yang mempunyai arus nominal sebesar 400 Ampere. Adapun alat ini berfungsi untuk mengukur tegangan dan arus pada tiap-tiap beban.

\section{i. Voltmeter}

Voltmeter yang digunakan dalam perancangan ini adalah voltmeter analog yang berjumlah dua buah. Voltmeter ini berfungsi untuk mengukur besar nilai tegangan pada setiap pembangkit (G1 dan G2).

j. Perancangan Program Delphi

Setelah perancangan interface pararel port, maka untuk dapat dilakukan pengontrolan monitoring dengan menggunakan komputer harus dirancanmg suatu program penyaklaran, yang dalam hal ini menggunakan Delphi. Program list-nya dapat dilihat pada lampiran.

\section{Struktur Perangkat Sistem Peralatan}

Secara struktural perangkat sistem peralatan ini akan diuraikan sebagai berikut:

\section{a. Perangkat Representasi Sistem Tenaga Listrik}

Perangkat representasi sistem tenaga listrik dalam penelitian ini berupa maket sistem tenaga listrik. Kedudukannya dalam hal ini adalah sebagai obyek dan berfungsi untuk menggambarkan kondisi sistem tenaga listrik. Maket yang sudah ada sebagai hasil penelitian pendahuluan tinggal dikembangkan menjadi maket yang representatif dalam jumlah busbar, pembangkit dan beban. Berdasarkan hasil penelitian pendahuluan seperti yang diperlihatkan dalam Gambar 2.3, maka ditetapkanlah jumlah busbar pada sistem beserta jenisnya (busbar beban atau busbar generator) yang dalam hal ini dipilih 2 (dua) buah busbar generator/pembangkit dan 3 (tiga) buah busbar beban. Maket lebih dikembangkan sehingga jelas terlihat mengenai lokasi pembangkit, gardu induk, saluran transmisi dan pusat-pusat beban.

b. Simulator Catu Daya Listrik (Generator)

Dalam penelitian ini dipilih simulator catu daya listrik berupa seperangkat sistem catu daya $a c$ enam-fasa. Fungsi dari catu daya $a c$ enam-fasa adalah untuk mensimulasikan pembangkit, yang mana terdiri dari peralatan:

* Tiga buah transformator satu-fasa centre-tap, 220/18 $\mathrm{V}, 15$ A. Fungsinya untuk membentuk sistem enamfasa $18 \mathrm{~V}$ pada sekundernya.

* Enam buah transformator satu-fasa biasa 18/220 V, 20 A. Fungsinya untuk menghasilkan sistem enamfasa dengan tegangan nominal yaitu $220 \mathrm{~V} /$ fasa. Tiga fasa seimbang akan mensimulasikan pembangkit nomor 1 dengan satu unit generator dan tiga fasa seimbang yang lainnya mensimulasikan pembangkit nomor 2 juga dengan satu unit generator. 
Cara membuat simulator generator ini adalah dengan menghubungkan ketiga transformator centre-tap secara tiga-fasa kemudian sisi masukannya disuplai dengan tegangan jala-jala (PLN) tiga-fasa. Selanjutnya enam buah keluaran dari bangku transformator centre-tap tap tadi menjadi masukan bagi ke-enam buah transformator satu-fasa biasa. Masukan dari masing-masing transformator satu-fasa biasa adalah tegangan rendah 18 V/fasa, dan kemudian di-step up menjadi $220 \mathrm{~V} /$ fasa. Jadi akan dihasilkan sistem ac enam-fasa dengan tegangan $220 \mathrm{~V} /$ fasa. Aksi kontrol yang dijalankan adalah sinkronisasi antara dua sistem pembangkit dengan sudut dayanyang sama.

c. Simulator Saluran Transmisi

Simulator saluran transmisi dalam penelitian ini adalah komponen-komponen resistansi (R) yang diwakili oleh elemen pemanas/dapur listrik (electric stove) dengan variasi resistansi, serta komponen induktansi (L) yang diwakili oleh ballast lampu TL $40 \mathrm{~W} / 220 \mathrm{~V}$ dan 20 W/220 V. Komponen R selanjutnya dihubung seri dengan komponen $\mathrm{L}$ membentuk impedansi saluran transmisi. Salah satu ujung dari saluran transmisi akan disaklarkan (switching) oleh komputer ke busbar.

d. Simulator Beban

Simulator beban dalam penelitian tahun ke-1 adalah beban statis yang diwakili beban tiga-fasa variabel berupa tahanan geser, induktor dan bank kapasitor yang ditempatkan pada dua buah busbar, serta beban dinamis yang diwakili oleh sebuah motor induksi tiga-fasa 220/380 V, 10 A yang akan ditempatkan pada busbar ketiga. Setiap beban akan disaklarkan oleh komputer ke busbar.

e. Panel/Rangkaian Instrumentasi dan Kontrol

Dalam penelitian ini panel kontrol berfungsi sebagai detector atau wadah tempat instrumen untuk melihat perubahan atau perlakuan yang diberikan pada besaranbesaran simulasi. Pada panel ditempatkan voltmeter, amperemeter, wattmeter dan power factor-meter.

f. Perangkat Interface

Alat ini penting keberadaannya karena perangkat mengkonversi besaran-besaran listrik analog menjadi besaran-besaran listrik digital yang dapat dibaca oleh komputer dan perangkat lunaknya. Besaran-besarn yang akan dideteksi adalah V, P, Q, I dan $\cos \phi$. Peralatan interface dalam hal ini berbasis mikrokontroler.

Diagram sistem peralatan secara keseluruhan dapat dilihat pada Gambar 1.

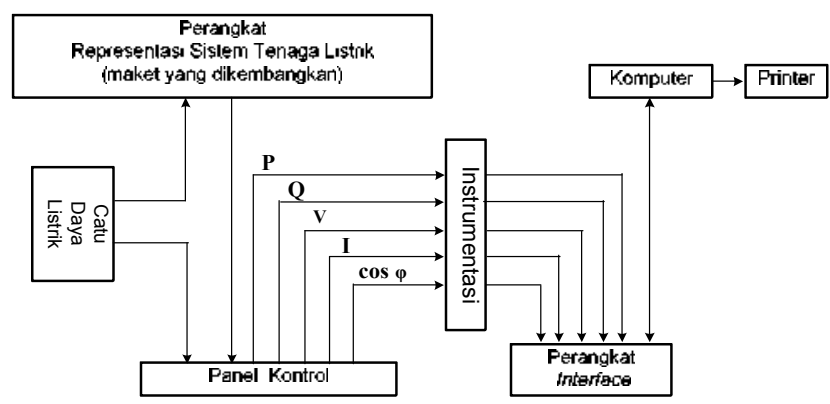

Gambar 1. Diagram sistem peralatan simulasi sistem tenaga listrik dan interface-nya yang dibuat.

\section{Hasil dan Pembahasan}

Peralatan simulasi aliran daya yang telah dirancang bangun seperti ditunjukkan pada Gambar 3.1 di atas, yang secara umum berfungsi sebagai alat untuk menguji dan mensimulasikan rancangan aliran daya untuk menyelesaikan permasalahan sistem aliran daya. Adapun fungsi

asing-masing komponennya ialah sebagai berikut:

A. Maket aliran daya, berfungsi sebagai objek untuk menggambarkan kondisi aliran daya.

B. Rangkaian control aliran daya berfungsi melihat perubahan dan perlakuan pada objek.

C. Panel control ke komputer untuk mengontrol perlakuan / perubahan terhadap sistem simulasi aliran daya.

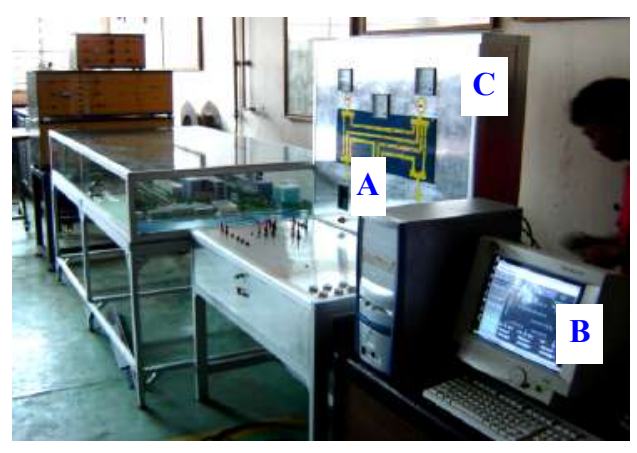

Gambar 2. Prototipe Sistem Aliran Daya 
Berdasarkan hasil eksekusi list program pada lampiran diperoleh tampilan simulasi aliran daya seperti pada Gambar 3. Pada gambar 3, terlihat 5 gardu induk yaitu 2 gardu induk pembangkit dan 3 gardu induk beban dengan 7 jaringan, bila sistem dimatikan atau dihidupkan cukup dilakukan dengan menklik switch yang diinginkan bila lampu indikator tidak menyala berarti jaringan dimatikan dan bila lampu hijau menyala berarti jaringan dihidupkan, begitu pula bila lampu merah menyalah berarti beban masuk ke sistem.

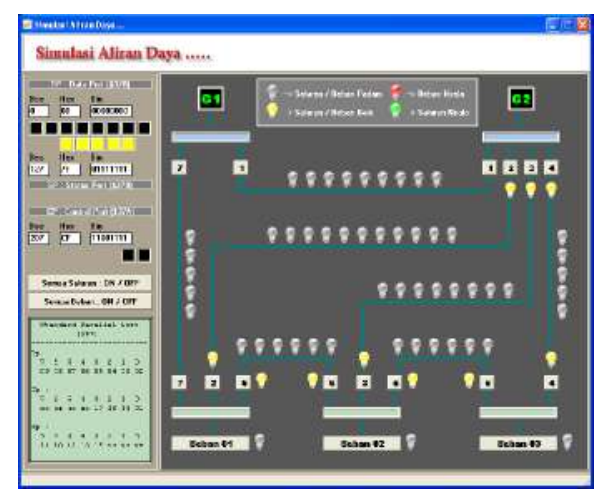

Gambar 3. Tampilan Program Simulasi Aliran Daya

Tabel 1. Data hasil pengujian untuk generator nomor 1 saja yang beroperasi.

\begin{tabular}{|c|c|c|c|c|c|c|}
\hline \multirow{3}{*}{$\mathbf{I}_{\mathbf{S} 1}$} & \multirow{2}{*}{\multicolumn{2}{|c|}{$\frac{\text { Beban } 1}{(1)}$}} & \multirow{2}{*}{\multicolumn{2}{|c|}{$\frac{\text { Beban 1-2 }}{(2)}$}} & \multirow{2}{*}{\multicolumn{2}{|c|}{$\frac{\text { Beban 1-2-3 }}{(3)}$}} \\
\hline & & & & & & \\
\hline & 0.14 & A & 0.13 & A & 0.12 & A \\
\hline $\mathbf{I}_{\mathbf{S} 2}$ & 0.017 & A & 0.11 & A & 0.1 & A \\
\hline $\mathbf{I}_{\mathbf{S} 3}$ & 0.13 & A & 0.06 & A & 0.06 & A \\
\hline $\mathbf{I}_{\mathbf{S} 4}$ & 0.12 & A & 0.09 & A & 0.08 & A \\
\hline $\mathbf{I}_{\mathbf{S 5}}$ & 0.17 & A & 0.1 & A & 0.1 & A \\
\hline $\mathbf{I}_{\mathbf{S 6}}$ & 0.13 & A & 0.06 & A & 0.08 & A \\
\hline $\mathbf{I}_{\mathbf{S} 7}$ & 0.017 & A & 0.11 & A & 0.1 & A \\
\hline $\mathbf{I}_{\mathbf{B} 1}$ & 0.1 & A & 0.06 & A & 0.05 & A \\
\hline $\mathbf{I}_{\mathbf{B} 2}$ & 0 & A & 0.2 & A & 0.22 & A \\
\hline $\mathbf{I}_{\mathbf{B} 3}$ & 0 & A & 0 & A & 0.06 & A \\
\hline $\mathbf{I}_{\mathrm{g} 1}$ & 0.21 & A & 0.32 & A & 0.33 & A \\
\hline $\mathbf{V}_{\mathrm{g} 1}$ & 175 & V & 145 & V & 140 & $\mathrm{~V}$ \\
\hline $\cos \varnothing$ & 0.91 & & 0.95 & & 0.94 & \\
\hline
\end{tabular}

\begin{tabular}{|c|cc|cc|cc|}
$\mathbf{V}_{\text {BUS-G1 }}$ & 175 & $\mathrm{~V}$ & 145 & $\mathrm{~V}$ & 140 & $\mathrm{~V}$ \\
\hline $\mathbf{V}_{\text {BUS-G2 }}$ & 135 & $\mathrm{~V}$ & 40 & $\mathrm{~V}$ & 40 & $\mathrm{~V}$ \\
\hline $\mathbf{V}_{\text {BUS-B1 }}$ & 120 & $\mathrm{~V}$ & 60 & $\mathrm{~V}$ & 60 & $\mathrm{~V}$ \\
\hline $\mathbf{V}_{\text {BUS-B2 }}$ & 130 & $\mathrm{~V}$ & 10 & $\mathrm{~V}$ & 10 & $\mathrm{~V}$ \\
\hline $\mathbf{V}_{\text {BUS-B3 }}$ & 135 & $\mathrm{~V}$ & 20 & $\mathrm{~V}$ & 35 & $\mathrm{~V}$ \\
\hline
\end{tabular}

Tabel 2. Data hasil pengujian untuk generator nomor 2 saja yang beroperasi.

\begin{tabular}{|c|c|c|c|c|c|c|}
\hline \multirow{3}{*}{$\mathbf{I}_{\mathrm{S} 1}$} & \multirow{2}{*}{\multicolumn{2}{|c|}{$\begin{array}{c}\text { Beban 1 } \\
(1) \\
\end{array}$}} & \multirow{2}{*}{\multicolumn{2}{|c|}{$\begin{array}{c}\text { Beban 1-2 } \\
(2)\end{array}$}} & \multirow{2}{*}{\multicolumn{2}{|c|}{$\frac{\text { Beban 1-2-3 }}{(3)}$}} \\
\hline & & & & & & \\
\hline & 0.026 & A & 0.027 & A & 0.024 & $\mathrm{~A}$ \\
\hline $\mathbf{I}_{\mathrm{S} 2}$ & 0.029 & $\mathrm{~A}$ & 0.028 & A & 0.026 & A \\
\hline $\mathbf{I}_{\mathrm{S} 3}$ & 0.062 & $\mathrm{~A}$ & 0.06 & A & 0.056 & $\mathrm{~A}$ \\
\hline $\mathbf{I}_{\mathrm{S} 4}$ & 0.039 & A & 0.48 & A & 0.044 & A \\
\hline $\mathbf{I}_{\mathbf{S 5}}$ & 0.026 & $\mathrm{~A}$ & 0.159 & A & 0.152 & A \\
\hline $\mathbf{I}_{\mathrm{S} 6}$ & 0.007 & A & 0.064 & A & 0.117 & A \\
\hline $\mathbf{I}_{\mathbf{S} 7}$ & 0.037 & A & 0.087 & A & 0.077 & A \\
\hline $\mathbf{I}_{\mathrm{B} 1}$ & 0.135 & $\mathrm{~A}$ & 0.039 & A & 0.032 & $\mathrm{~A}$ \\
\hline $\mathbf{I}_{\mathrm{B} 2}$ & 0 & $\mathrm{~A}$ & 0.28 & A & 0.3 & A \\
\hline$I_{B 3}$ & 0 & $\mathrm{~A}$ & 0 & A & 0.13 & A \\
\hline $\mathbf{I}_{\mathrm{g} 2}$ & 0.154 & $\mathrm{~A}$ & 0.334 & A & 0.311 & $\mathrm{~A}$ \\
\hline $\mathbf{V}_{\mathrm{g} 2}$ & 175 & V & 95 & $\mathrm{~V}$ & 80 & $\mathrm{~V}$ \\
\hline $\cos \varnothing$ & 0.9 & & 0.96 & & 0.95 & \\
\hline $\mathbf{V}_{\text {BUS-G1 }}$ & 140 & V & 55 & $\mathrm{~V}$ & 52 & V \\
\hline $\mathrm{V}_{\text {BUS-G2 }}$ & 175 & $\mathrm{~V}$ & 95 & $\mathrm{~V}$ & 80 & $\mathrm{~V}$ \\
\hline $\mathrm{V}_{\text {BUS-B1 }}$ & 125 & $\mathrm{~V}$ & 95 & V & 40 & $\mathrm{~V}$ \\
\hline $\mathrm{V}_{\text {BUS-B2 }}$ & 160 & $\mathrm{~V}$ & 15 & $\mathrm{~V}$ & 15 & $\mathrm{~V}$ \\
\hline$V_{\text {BUS-B3 }}$ & 115 & $\mathrm{~V}$ & 40 & $\mathrm{~V}$ & 75 & $\mathrm{~V}$ \\
\hline
\end{tabular}

Tabel 3. Data hasil pengujian untuk generator nomor 1 dan 2 beroperasi.

\begin{tabular}{|c|c|c|c|c|c|c|}
\hline & \multirow{2}{*}{\multicolumn{2}{|c|}{$\frac{\text { Beban } 1}{(1)}$}} & \multirow{2}{*}{\multicolumn{2}{|c|}{$\frac{\text { Beban 1-2 }}{(2)}$}} & \multirow{2}{*}{\multicolumn{2}{|c|}{$\frac{\text { Beban 1-2-3 }}{(3)}$}} \\
\hline & & & & & & \\
\hline $\mathbf{I}_{\mathbf{S} 1}$ & 0.12 & A & 0.11 & A & 0.11 & A \\
\hline $\mathbf{I}_{\mathbf{S} 2}$ & 0.11 & A & 0.1 & A & 0.9 & A \\
\hline $\mathbf{I}_{\mathbf{S 3}}$ & 0.1 & A & 0.1 & A & 0.1 & A \\
\hline $\mathbf{I}_{\mathrm{S} 4}$ & 0.06 & A & 0.04 & A & 0.05 & A \\
\hline $\mathbf{I}_{\mathbf{S 5}}$ & 0.12 & A & 0.14 & A & 0.12 & A \\
\hline $\mathbf{I}_{\mathbf{S 6}}$ & 0.06 & A & 0.07 & A & 0.11 & A \\
\hline $\mathbf{I}_{\mathbf{S} 7}$ & 0.19 & A & 0.22 & A & 0.25 & A \\
\hline $\mathbf{I}_{\mathbf{B} 1}$ & 0.04 & A & 0.04 & A & 0.05 & A \\
\hline $\mathbf{I}_{\mathbf{B} \mathbf{2}}$ & 0 & A & 0.13 & A & 0.15 & A \\
\hline $\mathbf{I}_{\mathbf{B} 3}$ & 0 & A & 0 & A & 0.12 & A \\
\hline $\mathbf{I}_{\mathrm{g} 1}$ & 0.32 & A & 0.3 & A & 0.31 & A \\
\hline
\end{tabular}




\begin{tabular}{|c|cc|cc|cc|}
$\mathbf{I}_{\mathbf{g} 2}$ & 0.3 & $\mathrm{~A}$ & 0.36 & $\mathrm{~A}$ & 0.36 & $\mathrm{~A}$ \\
\hline $\mathbf{V}_{\mathbf{g} 1}$ & 75 & $\mathrm{~V}$ & 60 & $\mathrm{~V}$ & 60 & $\mathrm{~V}$ \\
\hline $\mathbf{V}_{\mathbf{g} 2}$ & 75 & $\mathrm{~V}$ & 50 & $\mathrm{~V}$ & 45 & $\mathrm{~V}$ \\
\hline cos $\boldsymbol{\varnothing}$ & 0.98 & $\mathrm{~V}$ & 0.98 & $\mathrm{~V}$ & 0.98 & $\mathrm{~V}$ \\
\hline $\mathbf{V}_{\text {BUS-G1 }}$ & 75 & $\mathrm{~V}$ & 60 & $\mathrm{~V}$ & 60 & $\mathrm{~V}$ \\
\hline $\mathbf{V}_{\text {BUS-G2 }}$ & 75 & $\mathrm{~V}$ & 50 & $\mathrm{~V}$ & 45 & $\mathrm{~V}$ \\
\hline $\mathbf{V}_{\text {BUS-B1 }}$ & 60 & $\mathrm{~V}$ & 15 & $\mathrm{~V}$ & 20 & $\mathrm{~V}$ \\
\hline $\mathbf{V}_{\text {BUS-B2 }}$ & 52 & $\mathrm{~V}$ & 5 & $\mathrm{~V}$ & 5 & $\mathrm{~V}$ \\
\hline $\mathbf{V}_{\text {BUS-B3 }}$ & 60 & $\mathrm{~V}$ & 20 & $\mathrm{~V}$ & 40 & $\mathrm{~V}$ \\
\hline
\end{tabular}

a. Contoh Perhitungan Daya pada Busbar-G1

Daya Semu (S)

$$
\begin{aligned}
\mathrm{S} & =\mathrm{V}_{\mathrm{g} 1} \cdot \mathrm{I}_{\mathrm{g} 1} \\
& =175 \text { volt } \mathrm{x} 0,21 \text { ampere } \\
& =36,75 \mathrm{VA}
\end{aligned}
$$

Daya Aktif(P)

$$
\begin{aligned}
\mathrm{P} & =\mathrm{V} \text { I } \cos \phi \\
& =175 \times 0.21 \times 0,91 \\
& =33,4425 \text { watt }
\end{aligned}
$$

Daya Reaktif (Q)

$\mathrm{Q}=\mathrm{V} \mathrm{I} \sin \phi$

$\cos \phi=0,91 \Rightarrow \phi=24.49464847^{\circ}$

sehingga $\sin \phi=0.4146082248$

Jadi:

$$
\begin{aligned}
\mathrm{Q} & =175 \times 0.21 \times 0.4146082248 \\
& =15,2145 \mathrm{VAr}
\end{aligned}
$$

b. Contoh Perhitungan Rugi-Rugi Daya dari BusbarG1 ke Busbar-B1

$$
\begin{aligned}
& \text { Daya Semu (S) } \\
& \begin{aligned}
\mathrm{S}_{\text {loses }} & =\mathrm{S}_{\mathrm{G} 1}-\mathrm{S}_{\mathrm{B} 1} \\
& =36,75-12 \\
& =24,75 \mathrm{VA}
\end{aligned}
\end{aligned}
$$

Daya aktif (P)

$$
\begin{aligned}
\mathrm{P}_{\text {loses }} & =\mathrm{P}_{\mathrm{G} 1}-\mathrm{P}_{\mathrm{B} 1} \\
& =33,4425-10,92 \\
& =22,5225 \text { Watt } \\
\text { Daya Reaktif }(\mathrm{Q}) & \\
\mathrm{Q}_{\text {loses }} & =\mathrm{Q}_{\mathrm{G} 1}-\mathrm{Q}_{\mathrm{B} 1} \\
& =15,2145-4,9753 \\
& =10,2392 \text { VAR }
\end{aligned}
$$

\begin{tabular}{|c|c|c|c|c|c|c|c|}
\hline $\begin{array}{c}\text { BUS } \\
\mathbf{G}_{1} \text { ke } \\
\text { BUS } \\
\mathbf{G}_{2} \\
\text { (Volt) }\end{array}$ & $\begin{array}{c}\text { BUS } \\
\mathbf{G}_{1} \\
\text { ke } \\
\text { BUS } \\
\mathbf{B}_{1} \\
\text { (Vol } \\
\text { t) } \\
\end{array}$ & $\begin{array}{c}\text { BUS } \\
\mathbf{G}_{2} \text { ke } \\
\text { BUS } \\
\text { B }_{1} \\
\text { (Volt) }\end{array}$ & $\begin{array}{c}\text { BUS } \\
\mathbf{G}_{2} \text { ke } \\
\text { BUS } \\
\mathbf{B}_{2} \\
\text { (Volt) }\end{array}$ & $\begin{array}{c}\text { BUS } \\
\mathbf{G}_{2} \text { ke } \\
\text { BUS } \\
\mathbf{B}_{3} \\
\text { (Volt) }\end{array}$ & $\begin{array}{c}\text { BUS } \\
\text { B }_{1} \text { ke } \\
\text { BUS } \\
\text { B }_{2} \\
\text { (Volt) }\end{array}$ & $\begin{array}{c}\text { BUS } \\
\text { B }_{2} \text { ke } \\
\text { BUS } \\
\mathbf{B}_{3} \\
\text { (Volt) }\end{array}$ & $\begin{array}{c}\text { Ketera } \\
\text {-ngan }\end{array}$ \\
\hline 40 & 55 & 15 & 5 & 0 & -10 & -5 & $\begin{array}{c}\text { Beban } \\
1\end{array}$ \\
\hline 105 & 85 & -20 & 30 & 20 & 50 & -10 & $\begin{array}{c}\text { Beban } \\
1-2\end{array}$ \\
\hline 100 & 80 & -20 & 30 & 50 & 50 & -25 & $\begin{array}{c}\text { Beban } \\
1-2-3\end{array}$ \\
\hline
\end{tabular}

c. Contoh Perhitungan Jatuh Tegangan dari Busbar-G1

\begin{tabular}{|c|c|c|c|c|c|c|c|}
\hline $\begin{array}{c}\text { BUS } \\
\mathbf{G}_{2} \text { ke } \\
\text { BUS } \\
\mathbf{G}_{1} \\
(\text { Volt })\end{array}$ & $\begin{array}{c}\text { BUS } \\
\mathbf{G}_{1} \text { ke } \\
\text { BUS } \\
\mathbf{B}_{1} \\
\text { (Volt) }\end{array}$ & $\begin{array}{c}\text { BUS } \\
\mathbf{G}_{2} \text { ke } \\
\text { BUS } \\
\text { B }_{1} \\
\text { (Volt) }\end{array}$ & $\begin{array}{c}\text { BUS } \\
\mathbf{G}_{2} \text { ke } \\
\text { BUS } \\
\text { B }_{2} \\
\text { (Volt) }\end{array}$ & $\begin{array}{c}\text { BUS } \\
\text { G }_{2} \text { ke } \\
\text { BUS } \\
\mathbf{B}_{3} \\
\text { (Volt) }\end{array}$ & $\begin{array}{c}\text { BUS } \\
\text { B }_{1} \text { ke } \\
\text { BUS } \\
\text { B }_{2} \\
\text { (Volt) }\end{array}$ & $\begin{array}{c}\text { BUS } \\
\text { B }_{2} \text { ke } \\
\text { BUS } \\
\mathbf{B}_{3} \\
\text { (Volt) }\end{array}$ & $\begin{array}{c}\text { Ketera- } \\
\text { ngan }\end{array}$ \\
\hline 30 & 20 & 50 & 15 & 60 & 10 & 45 & $\begin{array}{c}\text { Beban } \\
1\end{array}$ \\
\hline 40 & -40 & 0 & 80 & 50 & 80 & -25 & $\begin{array}{c}\text { Beban } \\
1-2\end{array}$ \\
\hline 28 & 12 & 40 & 65 & 5 & 25 & -60 & $\begin{array}{c}\text { Beban } \\
1-2-3\end{array}$ \\
\hline
\end{tabular}
ke Busbar-B1.

$$
\begin{aligned}
\mathrm{V}_{\text {loss }} & =\mathrm{V}_{\mathrm{G} 1}-\mathrm{V}_{\mathrm{B} 1} \\
& =175-120 \\
& =50 \text { volt }
\end{aligned}
$$

d. Contoh Perhitungan Daya pada Busbar-B1

$$
\begin{aligned}
& \text { Daya Semu (S) } \\
& \begin{aligned}
\mathrm{S} & =\mathrm{V}_{\mathrm{BUS}-\mathrm{B} 1} \cdot \mathrm{I}_{\mathrm{B} 1} \\
& =120 \text { volt } \mathrm{x} 0,1 \text { ampere } \\
& =12 \mathrm{VA}
\end{aligned}
\end{aligned}
$$

$$
\begin{aligned}
& \text { Daya Aktif }(\mathrm{P}) \\
& \begin{aligned}
\mathrm{P} & =\mathrm{V}_{\mathrm{BUS}} \mathrm{B} 1 \mathrm{I}_{\mathrm{B} 1} \cos \phi \\
& =12 \times 0,1 \times 0,91 \\
& =10,92 \text { watt }
\end{aligned}
\end{aligned}
$$

\section{Daya Reaktif (Q)}

$\mathrm{Q}=\mathrm{V}_{\mathrm{BUS}-\mathrm{B} 1}-\mathrm{I}_{\mathrm{B} 1} \sin \phi$

$\cos \phi=0,91 \Rightarrow \phi=24,49464847^{\circ}$

sehingga $\sin \phi=0,4146082248$

Jadi:

$$
\begin{aligned}
\mathrm{Q} & =120 \times 0,1 \times 0,4146082248 \\
& =4,9753 \text { Var }
\end{aligned}
$$

Tabel 4. Hasil perhitungan jatuh tegangan antar busbar pada keadaan generator nomor 1 saja yang beroperasi.

Tabel 5. Hasil perhitungan jatuh tegangan antar busbar pada keadaan generator nomor 2 saja yang beroperasi. 
Tabel 6. Hasil perhitungan jatuh tegangan antar busbar pada keadaan generator nomor 1 dan nomor 2 beroperasi.

\begin{tabular}{|c|c|c|c|c|c|c|c|}
\hline $\begin{array}{c}\text { BUS } \\
\mathbf{G}_{1} \text { ke } \\
\text { BUS } \\
\mathbf{G}_{2} \\
\text { (Volt) }\end{array}$ & $\begin{array}{c}\text { BUS } \\
\text { G }_{1} \text { ke } \\
\text { BUS } \\
\text { B }_{1} \\
\text { (Volt) }\end{array}$ & $\begin{array}{c}\text { BUS } \\
\mathbf{G}_{2} \text { ke } \\
\text { BUS } \\
\mathbf{B}_{1} \\
\left(V_{0}\right) \text { ) } \\
\end{array}$ & $\begin{array}{c}\text { BUS } \\
\mathbf{G}_{2} \text { ke } \\
\text { BUS } \\
\mathbf{B}_{2} \\
\text { (Volt) } \\
\end{array}$ & $\begin{array}{c}\text { BUS } \\
\mathbf{G}_{2} \text { ke } \\
\text { BUS } \\
\mathbf{B}_{3} \\
\text { (Volt) }\end{array}$ & $\begin{array}{c}\text { BUS } \\
\text { B }_{1} \text { ke } \\
\text { BUS } \\
\text { B }_{2} \\
\text { (Volt) }\end{array}$ & $\begin{array}{c}\text { BUS } \\
\mathbf{B}_{2} \text { ke } \\
\text { BUS } \\
\mathbf{B}_{3} \\
\text { (Volt) }\end{array}$ & $\begin{array}{c}\text { Ketera- } \\
\text { ngan }\end{array}$ \\
\hline 0 & 15 & 15 & 23 & 15 & 8 & -8 & $\begin{array}{c}\text { Beban } \\
1\end{array}$ \\
\hline 10 & 60 & 35 & 45 & 30 & 10 & -15 & $\begin{array}{c}\text { Beban } \\
1-2\end{array}$ \\
\hline 25 & 40 & 20 & 40 & 5 & 15 & -35 & $\begin{array}{c}\text { Beban } \\
1-2-3\end{array}$ \\
\hline
\end{tabular}

\section{Kesimpulan}

Dari keseluruhan hasil analisa, simulasi dan pengamatan terhadap hasil pengujian yang dilakukan dalam penelitian ini, maka dapat dirumuskan beberapa kesimpulan dari tulisan ini. Adapun kesimpulan tersebut antara lain :

1. Dengan pemograman bahasa Delphi dapat dibuat simulasi penyaklaran pada aliran daya dengan 5 busbar (gardu induk) yaitu 2 busbar (gardu induk) pembangkit dan 3 busbar (gardu induk) beban dan 7 jaringan transmisi, dan semuanya dapat berfungsi dengan baik, serta dapat dikembangkan lebih banyak lagi gardu induk dan jaringan.

2. Dari hasil analisis data pengamatan/simulasi diperoleh bahwa : untuk G1 beroperasi sendiri maka daya terbesar yang dihasilkan adalah 44,08 watt bila beban 1-2 masuk, begitu pula bila G2 beroperasi sendiri maka dihasilkan daya sebesar 30.46 watt untuk beban yang sama, tetapi bila G1 dan G2 beroperasi daya terbesar diperoleh bila beban nomor 1 masuk yaitu sebesar 45.57 watt.

3. Tegangan di kedua busbar generator dalam keadaan beroperasi sendiri-sendiri mengalami penurunan yang signifikan, yaitu berturut-turut $20,5 \%-36,4 \%$ dan $20,5 \%-63,6 \%$ untuk pembangkit nomor 1 dan nomor 2, untuk kondisi pengoperasian satu hingga tiga busbar beban, yang menunjukkan bahwa jatuh tegangan terbesar terjadi pada busbar pembangkit dengan jumlah saluran tercatu paling banyak. Dengan mensimulasikan kedua pembangkit bekerja bersamaan, maka penurunan tegangan jauh lebih signifikan, yaitu berturut-turut $65,9 \%-72,7 \%$ dan $65,9 \%$ - 79,5\% untuk pembangkit nomor 1 dan nomor 2, untuk kondisi pengoperasian satu hingga tiga busbar beban.

4. Untuk rugi-rugi tegangan yang terbesar pada saat G1 beroperasi terjadi pada busbar G1 menuju busbar B1 sebesar 85 volt pada saat beban 1-2 masuk, sedangkan pada saat G2 beroperasi rugi-rugi tegangan terbesar terjadi pada busbar G2 menuju busbar B2 sebesar 80 volt, sedangkan apabila keduanya beroperasi rugi-rugi tegangan terbesar sebesar 60 volt dari busbar G1 menuju busbar B1 saat beban 1-2 masuk.

5. Dari ketiga operasi diatas, rugi-rugi tegangan terkecil terjadi bila G1 dan G2 beroperasi disemua saluran.

\section{Daftar Pustaka}

[1] Miller, R. H. dan J. H. Malinowski. 1994. Power System Operation. Third Edition. Boston: McGraw-Hill, Inc.

[2] Barret, J. P. 1997. Power System Simulation. SP Ringer : Technology and Industrial Arts.

[3] Glover, J. D. dan M. Sarma. 1994. Power System Analysis and Design [with Personal Computer Applications]. Second Edition. Boston : PWS Publishing Company.

[4] Das, J. C. 2002. Power System Analysis : Short Circuit, Load Flow and Harmonic. Marcel Delder

[5] Hadi, S. 1999. Power System Analysis. McGraw-Hill

[6] Powell, L. 2005. Power System Load Flow Analysis. Mc-Graw Hill Professional, Technological and Industrial Arts.

[7] Sianipar, G. Diktat Kuliah Penggunaan Komputer dalam Sistem Tenaga Listrik. Bandung : Jurusan Elektro ITB.

[8] Sudono, A. 2004. Memanfaatkan Port Printer Komputer Menggunakan Delphi : Teori dan Aplikasi. Semarang : Smart Books.

[9] Hutauruk, T. S. 1986. Analisa Sistem Tenaga : Jilid I dan Jilid II. ITB : Jurusan Teknik Elektro. 